\title{
ILMU PENDIDIKAN ISLAM (ANTARA TRADISIONAL DAN MODERN)
}

\section{Summary by: Tabrani. ZA}

\author{
Judul Buku : Ilmu Pendidikan Islam (Antara Tradisonal dan Modern) \\ Penulis : Tabrani. ZA \\ Penerbit : Al-Jenderami Press \\ Kota : Kuala Lumpur \\ Negara : Malaysia \\ Tahun : 2009 \\ Type File : Ringkasan Buku
}

\section{SUMMARY}

Pengetahuan yang merupakan produk kegiatan berpikir merupakan obor pencerahan peradaban di mana manusia menemukan dirinya dan menghayati hidup dengan lebih sempurna. Berbagai peralatan dikembangkan manusia untuk meningkatkan kualitas hidupnya dengan menerapkan pengetahuan yang diperolehnya. Proses penemuan dan penerapan itulah yang menghasilkan kapak dan batu zaman dulu sampai komputer zaman ini. Pengetahuan yang merupakan produk kegiatan berpikir merupakan obor pencerahan peradaban di mana manusia menemukan dirinya dan menghayati hidup dengan lebih sempurna. Pendidikan Islam adalah suatu wacana yang mengandalkan ideologi Islam sendiri sebagai pegangan pendidikan tersebut. Maka konstruksi pendidikan Islam merupakan upaya untuk mencocokkan kembali kiranya hal yang perlu diperbaiki atau menaruh pendidikan islam itu sendiri di dalam kebutuhan teori-teori tertentu. Pendidikan Islam seyogianya harus mampu merubah diri, bukan hanya bersikap mengedepankan ilmu-ilmu agama (ulum al-din) saja, tetapi pendidikan Islam juga harus mampu menjawab tantangan zaman. Tujuan pendidikan Islam seyogianya tidak hanya bertujuan untuk kebahagiaan ukhrawi saja, tetapi juga harus bertujuan untuk kebahagiaan duniawi. Pendidikan Islam harus mampu memasukkan IPTEK ke dalam kurikulum pendidikannya, sehingga peserta didik mampu menguasai IPTEK sebagai bekal mereka untuk menaungi samudra kehidupan. Di sinilah kemudian penting untuk memadukan sistem pendidikan Islam tradisional dengan sistem pendidikan Islam modern. Kedua jenis pendidikan Islam (tradisional dan modern) tetap selalu dibutuhkan.

Keywords: Pendidikan Islam, Tradisional, Modern, Pengetahuan, IPTEK

\section{PENDAHULUAN}

Pendidikan Islam berkembang seiring dengan kemunculan Islam itu sendiri. Pada masa awal perkembangan Islam, pendidikan formal yang sistematis belum terselenggara. Pendidikan yang berlangsung dapat dikatakan umunya bersifat informal; dan inipun lebih berkaitan dengan uapay-upaya dakwah Islamiyah. Dalam pendidikan informal ini proses 
belajar mengajar berlangsung di rumah sahabat tertentu, dan yang paling terkenal adalah Darul Arqom, akan tetapi setelah masyarakat Islam mulai terbentuk, maka pendidikan berlangsung di masjid. Proses pendidikan pada kedua tempat ini dilakukan dalam halaqoh, lingkaran belajar. Pendidikan formal Islam baru muncul pada masa lebih belakangan ini, yakni dengan adanya madrasah-madrasah, beberapa sejarawan pendidikan mengemukakan, bahwa madrasah pertama di dirikan oleh Wazir Nizham al-Mulk pada tahun 1064. Madrasah ini kemudian terkenal sebagai madrasah Nizham Al-Mulk.

Pendidikan merupakan proses budaya untuk meningkatkan harkat dan martabat manusia yang berlangsung sepanjang hayat. Pendidikan selalu berkembang, dan selalu dihadapkan pada perubahan zaman. Untuk itu, mau tak mau pendidikan harus didisain mengikuti irama perubahan tersebut, apabila pendidikan tidak didisain mengikuti irama perubahan, maka pendidikan akan ketinggalan dengan lajunya perkembangan zaman itu sendiri. Pendidikan dari masyarakat, didisain mengikuti irama perubahan dan kebutuhan masyarakat. Misalnya; pada peradaban masyarakat agraris, pendidikan didisain relevan dengan irama perkembangan peradaban masyarakat agraris dan kebutuhan masyarakat pada era tersebut. Begitu juga pada peradaban masyarakat industrial dan informasi, pendidikan didisain mengikuti irama perubahan dan kebutuhan masyarakat pada era industri dan informasi, dan seterusnya. Demikian siklus perkembangan perubahan pendidikan, kalau tidak pendidikan akan ketinggalan dari perubahan zaman yang begitu cepat. Untuk itu perubahan pendidikan harus relevan dengan perubahan zaman dan kebutuhan masyarakat pada era tersebut, baik pada konsep, materi dan kurikulum, proses, fungsi serta tujuan lembaga-lembaga pendidikan.

Hakekat dari sebuah pendidikan adalah sebuah upaya atau proses pengubahan bentuk sikap atau tata laku seseorang atau kelompok dalam upaya untuk mendewasakan manusia melalui upaya pelaksanaan kegiatan pendidikan dan pengajaran dengan cara berpegang teguh kepada norma atau kebiasaan yang sudah berlangsung sejak lama yang terjadi secara turun temurun. Terdapat beberapa pola yang telah disajikan oleh sejarah pendidikan, yaitu pola pendidikan yang menggunakan system tradisional yang menurut sebagian orang diidentikkan dengan pesantren yang secara nonformal dilakukan melalui pendekatan takhassus, kaderisasi, Ijazah dan lain sebagainya. 
Pengetahuan yang merupakan produk kegiatan berpikir merupakan obor pencerahan peradaban di mana manusia menemukan dirinya dan menghayati hidup dengan lebih sempurna. Berbagai peralatan dikembangkan manusia untuk meningkatkan kualitas hidupnya dengan menerapkan pengetahuan yang diperolehnya. Proses penemuan dan penerapan itulah yang menghasilkan kapak dan batu zaman dulu sampai komputer zaman ini. Pengetahuan yang merupakan produk kegiatan berpikir merupakan obor pencerahan peradaban di mana manusia menemukan dirinya dan menghayati hidup dengan lebih sempurna. Filsafat merupakan ilmu yang berusaha untuk memahami semua hal yang timbul di dalam keseluruhan lingkup pengalaman manusia. Berfilsafat adalah berpikir, dan malahan sampai kepada berspekulasi. Filsafat menghendaki olah pikir yang sadar, yang berarti teliti dan teratur. Epistemologi filsafat pendidikan Islam adalah suatu ilmu yang mengkaji tentang prosedur, proses memperoleh filsafat pendidikan Islam dengan cara mengkaji pada wahyu dan fenomena alam semesta.

Epistemologi berorientasi pada bagaimana membangun paradigma pendidikan Islam yang tetap sesuai dengan alqur'an dan hadis. Berlandaskan kerangka filsafat pendidikan Islam ini maka diharapkan potensi intelektual dan spiritual manusia itu tumbuh dengan baik sehingga tercipta manusia super yang mempunyai kecerdasan spritual sekaligus emosional-spritual. Epistemologi filsafat pendidikan Islam ini digunakan untuk memperoleh pengetahuan pendidikan Islam. Sistem yang digunakan dalam pendidikan tradisional ini adalah dengan cara melihat sejarah masa lalu sebagai inspirasi atau sesuatu yang harus dipertahankan. Akar teologis pemikiran tradisionalis tersebut adalah manusia itu harus menerima segala ketentuan dan rencana Tuhan yang telah dibentuk sebelumnya.

Manusia merupakan makhluk sosial dan berperadaban. Pendidikan merupakan term kunci dalam perubahan masyarakat. Bahkan Islam sendiri menempatkan pendidikan dalam posisi utama. Tak heran jika dalam ajaran Islam yang dikembangkan Rasulullah SAW melalui pendekatan pendidikan. Hal ini bisa dipahami jika kita mengingat ayat pertama yang diwahyukan kepada Rasulullah SAW, dari lima pertama dalam surat al-'Alaq, merupakan perintah untuk membaca atau lebih tepatnya untuk memahami.

Proses pendidikan merupakan rangkaian usaha membimbing, mengarahkan kemampuan-kemampuan dasar dan potensi belajar, agar 
peserta didik bisa tumbuh secara baik dan mengembangkan potensi dirinya secara positif di dalam kehidupan sehari-hari, baik sebagai individu ataupun anggota sosial dan alam sekitar. Tuntutan ini tentunya mengharuskan penanaman nilai-nilai pendidikan dan akhlaq al-karimah, sehingga dengan proses tersebut dapat mewujudkan manusia yang berilmu dan berpribadi luhur.

Bimbingan dan pembinaan tersebut tidak hanya berorientasi pada daya pikir (intelektual) saja, akan tetapi juga pada segi emosional yang dengan pembinaan dan bimbingan akan dapat membawa perubahan pada arah yang lebih positif. Dari paradigma sebelumnya dapat dipahami bahwa, pendidikan adalah suatu usaha yang dilakukan dengan penuh kesadaran dan terkonsep serta terencana untuk memberikan pembinaan dan pembimbingan pada peserta didik (anak-anak). Sehingga Pendidikan Islam merupakan suatu sistem yang memungkinkan seseorang (peserta didik) dapat mengarahkan kehidupannya sesuai dengan ideologi Islam. Ia dapat dengan mudah membentuk kehidupan dirinya sesuai dengan nilai-nilai ajaran Islam yang diyakininya.

\section{PENDIDIKAN ISLAM TRADISIONAL}

Pendidikan adalah sebuah proses pengubahan sikap atau tata laku seseorang untuk mendewasakan manusia melalui upaya pelaksanaan pengajaran dengan cara berpegang teguh kepada norma yang sudah lama terjadi secara turun temurun. Pendidikan tradisional di identikkan dengan pendidikan pesantren yang pelaksanaannya dilaksanakan secara nonformal melalui pendekatan takhassus, kaderisasi.

Ilmu pengetahuan dalam perspektif Islam berasal dari Tuhan. Jika terdapat perbedaan antara penginderaan dengan wahyu, maka pemikir Islam akan lebih mempercayai dan mendahulukan otoritas kebenaran wahyu daripada hasil penginderaan, karena kebenaran wahyu dianggap sebagai kebenaran sejati dan mutlak. Pada masa Islam Klasik pendidikan dikelompokkan dalam dua kategori, yaitu lembaga formal dan lembaga sampingan (informal) (kuttab, shuffauh, halaqoh, qushur, majlis dan masjid serta rumah ulama) dan mereka mempunyai ciri yang masingmasing. Orientasi pendidikan tradisional adalah mengemban tugas suci, yaitu menyebarkan agama.

Konsep Islam tradisional masih sangat urgen bagi kehidupan masyarakat, mengingat Islam tradisional dapat menyatukan antara praktek ajaran Islam dengan sumber ajaran Islam. Keberadaan Islam tradisional 
sudah menjadi budaya di dalam kehidupan masyarakat lokal maupun masyarakat non lokal, dan keberadaan Islam tradisional merupakan perpaduan antara budaya lokal dengan Nilai-nilai ke-Islaman. Sehingga Islam tradisional dapat hidup sejalan antara realitas kehidupan masyarakat secara universal dengan Nilai-nilai ke-Islaman. Maka dari itu Islam tradisional dapat digolongkan sebuah gagasan mendekatkan antara teks dan konteks dalam Ilmu Ke-Islaman saat ini, untuk itu dibutuhkan kajian yang mendalam tentang Islam tradisional yang tumbuh kembang di tengah-tengah realitas kehidupan masyarakat saat ini.

Ada dua model pendidikan sebagai representasi pendidikan Islam yang berkembang di Indonesia sejak masuknya Islam hingga memasuki abad ke-20, yaitu, yaitu model pesantren dan surau. Model pesantren tumbuh dan berkembang di Jawa, sedangkan surau di Sumatera. Kedua model pendidikan ini masih sangat tradisional, konservatif, kolot dan tidak memenuhi standar pendidikan Eropa. Dari aspek manajemen, pesantren ataupun surau dipimpin oleh seorang Kiyai. Kiyai adalah figur tunggal dan sentral yang memiliki otoritas penuh dalam segala hal terhadap murid atau santrinya, bahkan masyarakat luas.

Dalam pandangan kiyai, seperti disebut Dhofier, pesantren yang dipimpinnya seperti kerajaan kecil dan dirinya sebagai sumber mutlak atas seluruh kewenangan atau kekuasaan dalam kehidupan pesantren. Selain sebagai guru, kiyai adalah sosok yang sangat dihormati dan disegani serta dipercaya mampu memberikan berkah dan celaka, bahkan dianggap ma'shum (tanpa salah dan dosa). Selain itu, telah menjadi kebiasaan kiyai dijadikan sebagai tabib, hakim, konsultan magis dan sebagai tempat menggantungkan hidup dan masa depan para santri.

Bagi santri, kehinaan dan ketundukannya kepada kiyai adalah sebuah kebanggaan, dan kerendahan hati terhadapnya adalah keluhuran. Itu sebabnya, seorang santri akan sangat bahagia dan bangga sekaligus dengan etos kerja tinggi bila dapat membantu kiyai menyelesaikan pekerjaan rumah tangga kiyai misalnya.

Dari aspek proses pendidikan, hampir dipastikan metode pembelajaran dengan menggunakan metode ceramah yang monoton, tanpa dialog. Materi yang diajarkan hanya terfokus pada pelajaran agama seperti tertuang dalam kitab Islam klasik, misalnya terkait dengan praktik salat lima waktu, khutbah, salat jumat dan lainnya.

Jika diklasifikasikan, kitab yang dipelajari di pesantren dapat dibagi menjadi 8, yaitu: nahwu, sharaf, fikih, usul fikih, hadis, tafsir, tauhid, 
tasawuf dan etika, serta cabang-cabang yang lain seperti tarikh, dan balaghah Dari 8 jenis kitab tersebut, pengajaran fikih, nahwu, sharaf dan akidah menjadi prioritas. Sedangkan pengajaran tasauf, tafsir al-Qur'an, dan juga hadis sebagai ilmu yang bersifat sophisticated, yang hanya dapat dipelajari oleh orang-orang tertentu. Tidak ditemukan kitab/buku umum sebagai bahan ajarnya.

Dalam studi kependidikan, sebutan "Pendidikan Islam" pada umumnya dipahami sebagai suatu ciri khas, yaitu jenis pendidikan yang berlatar belakang keagamaan. Dapat juga digambarkan bahwa pendidikan yang mampu membentuk "manusia yang unggul secara intelektual, kaya dalam amal, dan anggun dalam moral". Hal ini berarti menurut cita-citanya pendidikan Islam memproyeksi diri untuk memproduk "insan kamil", yaitu manusia yang sempurna dalam segala hal, sekalipun diyakini baru (hanya) Nabi Muhammad SAW yang telah mencapai kualitasnya.

Pendidikan Islam adalah suatu wacana yang mengandalkan ideologi Islam sendiri sebagai pegangan pendidikan tersebut. Maka konstruksi pendidikan Islam merupakan upaya untuk mencocokkan kembali kiranya hal yang perlu diperbaiki atau menaruh pendidikan islam itu sendiri di dalam kebutuhan teori-teori tertentu. Jika berbicara mengenai pendidikan salah satu yang terpenting adalah tujuan' yang ingin dicapai oleh pendidikan tersebut. Syamsul Arifin menyebutkan bahwa tujuan merupakan salah satu komponen pendidikan yang terpenting Seluruh aktivitas pendidikan sangat tergantung pada rumusan tujuan pendidikan. Atau dengan kata lain, aktivitas pendidikan terutama yang berbentuk aktivitas belajar mengajar dimaksudkan untuk merealisasikan tujuan pendidikan. Dalam tujuan pendidikan terdapat rumusan gambaran nilainilai ideal pribadi manusia yang ingin dilahirkan dari lembaga pendidikan. Jika tekanan tujuan pendidikan pada kualitas pribadi manusia, tidak berarti cakupan pendidikan menyempit pada manusia sebagai individu.

Maka di dalam pendidikan Islam tujuan yang dapat digambarkan adalah pendidikan yang bertujuan untuk memberikan suplai pengetahuan yang berbasis pada ilmu Islam itu sendiri, yang kemudian mampu diaktualisasikan ke dalam kehidupan sosial bermasyarakat. Dengan itu ilmu bisa dikatakan sebagai alat yang mampu memberikan nilai-nilai praktis bagi manusia itu sendiri.

Pendidikan merupakan usaha sadar yang dilakukan oleh manusia untuk mengembangkan potensi manusia lain atau memindahkan nilai-nilai yang dimilikinya kepada orang lain dalam masyarakat. Proses pemindahan 
nilai ini dapat dilakukan dengan berbagai cara, di antaranya adalah: pertama, melalui pengajaran yaitu proses pemindahan nilai berupa (ilmu) pengetahuan dari seorang guru kepada murid-muridnya dari satu generasi ke generasi berikutnya.

Kedua, melalui pelatihan yang dilaksanakan dengan jalan membiasakan seseorang melakukan pekerjaan tertentu untuk memperoleh keterampilan mengerjakan pekerjaan tersebut. Ketiga, melalui indoktrinasi yang diselenggarakan agar orang meniru atau mengikuti apa saja yang diajarkan orang lain tanpa mengizinkan si penerima tersebut mempertanyakan nilai-nilai yang diajarkan Begitu pula dengan pendidikan Islam dalam kacamata feminisme, di bagian tertentu dalam hal ini pendidikan islam sebagai sebuah perlawanan.

\section{PENDIDIKAN ISLAM MODERN}

Melihat perkembangan ilmu pengetahuan dan teknologi yang semakin pesat, maka pendidikan Islam dituntut untuk bergerak dan mengadakan inovasi-inovasi dalam pendidikan. Mulai dari paradigma, sistem pendidikan dan metode yang digunakan. Ini dimaksudkan agar perkembangan pendidikan Islam tidak tersendat-sendat. Sebab kalau pendidikan Islam masih berpegang kepada tradisi lama yang tidak dapat menyesuaikan diri dengan perkembangan IPTEK, maka pendidikan Islam akan buntu.

Adapun agar pendidikan Islam terus berkembang dan selalu sesuai dengan perkembangan ilmu pengetahuan dan teknologi, maka perlu adanya integrasi antara pendidikan Islam Tradisional dan pendidikan Islam modern. Selain itu juga perlu adanya rekonstruksi metode atau model pembelajaran yang digunakan di dalam pendidikan Islam. Ini diharapkan dapat mengikuti tuntutan anak modern yang selalu kritis dan lebih berpikiran maju dari anak zaman dahulu yang cenderung manut dan tunduk terhadap apa yang disampaikan guru. Pendidikan Islam ke depan harus lebih memprioritaskan kepada ilmu terapan yang sifatnya aplikatif, bukan saja dalam ilmu-ilmu agama akan tetapi juga dalam bidang teknologi. Bila dianalisis lebih jeli selama ini, khususnya sistem pendidikan Islam seakan-akan terkotak-kotak antara urusan duniawi dengan urusan ukhrawi, ada pemisahan antara keduanya. Sehingga dari paradigma yang salah itu, menyebabkan umat Islam belum mau ikut andil atau berpartisipasi banyak dalam agenda-agenda yang tidak ada hubungannya dengan agama, begitu juga sebaliknya. Agama mengasumsikan atau 
melihat suatu persoalan dari segi normatif (bagaimana seharusnya), sedangkan sains meneropongnya dari segi objektifnya (bagaimana adanya). Sebagai permisalan tentang sains, sering kali umat Islam phobia dan merasa sains bukan urusan agama begitu juga sebaliknya. Dalam hal ini ada pemisahan antara urusan agama yang berorientasi akhirat dengan sains yang dianggap hanya berorientasi dunia saja.

Islam bukanlah agama sekuler yang memisahkan urusan agama dan dunia. Dalam Islam, agama mendasari aktivitas dunia, dan aktivitas dunia dapat menopang pelaksanaan ajaran agama. Islam bukan hanya sekedar mengatur hubungan manusia dengan Tuhan sebagaimana yang terdapat pada agama lain, melainkan juga mengatur hubungan manusia dengan manusia dan manusia dengan dunia. Islam adalah agama yang ajaranajarannya diwahyukan Tuhan kepada manusia melalui Nabi Muhammad SAW sebagai rasul. Islam pada hakikatnya, membawa ajaran-ajaran yang bukan hanya mengatur satu segi, tetapi mengenai berbagai segi kehidupan manusia. Sumber dari ajaran-ajaran yang mengambil berbagai aspek itu ialah al-Qur'an dan as-Sunnah.

Masalah pendidikan memang tidak akan pernah selesai dibicarakan oleh siapapun. Hal ini setidak-tidaknya didasarkan pada beberapa alasan: pertama, merupakan fitrah orang bahwa mereka menginginkan pendidikan yang lebih baik, sekalipun mereka kadang-kadang belum tahu sebenarnya mana pendidikan yang lebih baik itu. Karena sudah fitrahnya, sehingga sudah menjadi takdirnya pendidikan itu tidak pernah selesai. Gagasan tentang no limit to study atau life long education merupakan implikasi praktis dari fitrah tersebut. Kedua, teori pendidikan akan selalu ketinggalan zaman, karena ia dibuat berdasarkan kebutuhan masyarakat yang selalu berubah pada setiap tempat dan waktu. Karena adanya perubahan itu maka masyarakat tidak pernah puas dengan teori pendidikan yang ada. Ketiga, perubahan pandangan hidup juga ikut berpengaruh terhadap ketidakpuasan seseorang akan pendidikan.

Pendidikan dalam pengertian yang lebih luas dapat diartikan sebagai suatu proses pembelajaran kepada peserta didik (manusia) dalam upaya mencerdaskan dan mendewasakan peserta didik tersebut. Dalam hubungannya ini dapat dipastikan bahwa pendidikan itu tidak hanya menumbuhkan, melainkan mengembangkan ke arah tujuan akhir. Juga tidak hanya suatu proses yang sedang berlangsung, melainkan suatu proses yang berlangsung ke arah sasarannya. Sedangkan "Pendidikan Islam adalah ilmu pendidikan yang berdasarkan Islam. Islam adalah nama 
agama yang dibawa oleh Nabi Muhammad Saw. Islam berisi seperangkat ajaran tentang kehidupan manusia, ajaran itu dirumuskan berdasarkan dan bersumber pada al-Qur'an dan hadits.

Ilmu pendidikan Islam dapat diartikan sebagai studi tentang proses kependidikan yang didasarkan pada nilai-nilai filosofis ajaran berdasarkan Al-Qur`an dan Sunnah Nabi Muhammad SAW. Dengan redaksi yang sangat singkat, ilmu pendidikan Islam adalah ilmu pendidikan yang berdasarkan Islam. Kata "Islam" yang berada di belakang "pendidikan" selain menjadi sumber motivasi, inspirasi, sublimasi dan integrasi bagi pengembangan bagi ilmu pendidikan, juga sekaligus menjadi karakter dari ilmu pendidikan Islam itu sendiri. Ilmu pendidikan Islam yang berkarakter Islam itu adalah ilmu pendidikan yang sejalan dengan nilai-nilai luhur yang terdapat di dalam AlQur`an dan Sunnah.

Pendidikan Islam adalah sebuah sarana atau pun furshoh untuk menyiapkan masyarakat muslim yang benar-benar mengerti tentang Islam. Di sini para pendidik muslim mempunyai satu kewajiban dan tanggung jawab untuk menyampaikan ilmu yang dimilikinya kepada anak didiknya, baik melalui pendidikan formal maupun non formal. Pendidikan Islam berbeda dengan pendidikan yang lain. Pendidikan Islam lebih mengedepankan nilai-nilai keislaman dan tertuju pada terbentuknya manusia yang ber-akhlakul karimah serta taat dan tunduk kepada Allah semata. Sedangkan pendidikan selain Islam, tidak terlalu memprioritaskan pada unsur-unsur dan nilai-nilai keislaman, yang menjadi prioritas hanyalah pemenuhan kebutuhan inderawi semata.

Pendidikan Islam ke depan harus lebih memprioritaskan kepada ilmu terapan yang sifatnya aplikatif, bukan saja dalam ilmu-ilmu agama akan tetapi juga dalam bidang teknologi. Bila dianalisis lebih jeli selama ini, khususnya sistem pendidikan Islam seakan-akan terkotak-kotak antara urusan duniawi dengan urusan ukhrawi, ada pemisahan antara keduanya. Sehingga dari paradigma yang salah itu, menyebabkan umat Islam belum mau ikut andil atau berpartisipasi banyak dalam agendaagenda yang tidak ada hubungannya dengan agama, begitu juga sebaliknya. Agama mengasumsikan atau melihat suatu persoalan dari segi normatif (bagaimana seharusnya), sedangkan sains meneropongnya dari segi objektifnya (bagaimana adanya). Sebagai permisalan tentang sains, sering kali umat Islam Phobia dan merasa sains bukan urusan agama begitu juga sebaliknya. Dalam hal ini ada pemisahan antara urusan agama 
yang berorientasi akhirat dengan sains yang dianggap hanya berorientasi dunia saja. Di sini sangat jelas pemisahan dikotomi ilmu tersebut.

Pendidikan modern, memiliki beberapa karakteristik tersendiri bila dibandingkan dengan pendidikan tradisional. Hal ini dikarenakan pendidikan modern, jelas lebih mengarah mengikuti perubahan zaman. Ciri khas pendidikan Islam modern, bukan hanya bersifat ukhrawi saja, tetapi juga berbicara tentang duniawi, sehingga pendidikan modern ini mengarah kepada 2 kebahagiaan, yaitu kebahagiaan dunia dan kebahagiaan akhirat. Proses pembelajarannya pun bukan hanya terfokus kepada guru, tetapi seluruh komponen merupakan pusat pembelajaran termasuk lingkungan dan murid. Hal ini diarahkan, siswa bukan hanya hebat di sisi kognitif saja, tetapi juga dari segi afektif dan psikomotorik juga mengena kepada siswa.

Islam bukanlah agama sekuler yang memisahkan urusan agama dan dunia. Dalam Islam, agama mendasari aktivitas dunia, dan aktivitas dunia dapat menopang pelaksanaan ajaran agama. Islam bukan hanya sekedar mengatur hubungan manusia dengan Tuhan sebagaimana yang terdapat pada agama lain, melainkan juga mengatur hubungan manusia dengan manusia dan manusia dengan dunia. Islam adalah agama yang ajaranajarannya diwahyukan Allah kepada manusia melalui Nabi Muhammad SAW sebagai rasul. Islam pada hakikatnya, membawa ajaran-ajaran yang bukan hanya mengatur satu segi, tetapi mengenai berbagai segi kehidupan manusia. Sumber dari ajaran-ajaran yang mengambil berbagai aspek itu ialah AlQur`an dan al-Sunnah.

Apabila ingin merekonstruksi pendidikan Islam di era modern ini, persoalan pertama yang harus di tuntaskan adalah persoalan "dikotomi". Artinya harus berusaha mengintegrasikan kedua ilmu tersebut baik secara filosofis, kurikulum, metodologi, pengelolaan, bahkan sampai pada departementalnya. Perubahan orientasi pendidikan Islam harus dilakukan yaitu "bukan hanya bagaimana membuat manusia sibuk mengurusi dan memuliakan Tuhan dengan melupakan eksistensinya, tetapi bagaimana memuliakan Tuhan dengan sibuk memuliakan manusia dengan eksistensinya di dunia ini. Artinya, bagaimana pendidikan Islam harus mampu mengembangkan potensi manusia seoptimal mungkin sehingga menghasilkan manusia yang memahami eksistensinya dan dapat mengelola dan memanfaatkan dunia sesuai dengan kemampuannya.

Dengan dasar ini, maka materi pendidikan Islam harus di desain untuk dapat mengakomodasi persoalan-persoalan yang menyangkut dengan 
kebutuhan manusia, yaitu mengembangkan pengetahuan dan keterampilan, teknologi, seni serta budaya, sehingga mampu melahirkan manusia yang berkualitas, handal dalam penguasaan ilmu pengetahuan, keterampilan, unggul dalam moral yang di dasarkan pada nilai-nilai ilahiah sebagai produk pendidikan Islam. Dengan kata lain pendidikan dalam hal ini pendidikan Islam, akan menghasilkan ilmuan yang tidak hanya unggul dalam ilmu sains akan tetapi juga ilmuan yang tahu posisinya sebagai khalifah di muka bumi, yang bertakwa kepada Allah SWT, serta menjalankan apa yang diperintah dan menjauhkan apa yang dilarang oleh-Nya.

Dalam kehidupan sosial, institusi pendidikan baik umum maupun Islam, mendapat tugas suci untuk mengemban misi mulia agar membenahi kualitas hidup manusia jadi lebih baik. Suatu misi (risalah) kemanusiaan yang sangat bermanfaat dalam rangka membentuk sikap mental lulusan yang berperadaban dan menjunjung tinggi nilai insani. Pendidikan Islam harus menjadi kekuatan (power) yang ampuh untuk menghadapi wacana kehidupan yang lebih krusial. Refleksi pemikiran dan rumusan persoalan pendidikan Islam harus bernafaskan kekinian (up to date). Jika dipandang secara historis, memang adanya suatu kejadian yang telah lalu, dapat dijadikan sebuah pelajaran untuk menjadi lebih baik lagi, tapi jangan sampai melupakan perhatian yang perlu diberikan di masa kini dan masa mendatang. Pendidikan Islam harus menjadi terobosan baru untuk membentuk pola hidup umat yang lebih maju dan terbebas dari kebodohan dan kemiskinan. Sebab secara filosofi yang sudah tidak asing lagi untuk diketahui bahwa antara kebodohan dan kemiskinan itu merupakan dua sifat manusia yang mengkristal dan menjadi musuh bebuyutan pendidikan.

Rumusan tujuan pendidikan mestinya bukan hanya bersifat kehidupan akhirat, tetapi juga bersifat duniawi. Dalam implikasinya, tujuan pendidikan Islam mestinya lebih bersifat metafisik. Secara umum, misalnya, pendidikan Islam bertujuan untuk meningkatkan keimanan, pemahaman, penghayatan dan pengalaman peserta didik tentang agama Islam, sehingga menjadi manusia muslim yang beriman dan bertakwa kepada Allah serta berakhlak mulia dalam kehidupan pribadi, bermasyarakat, berbangsa dan bernegara. Terlihat rumusan ini bersifat normatif dan tidak bersifat problematik.

Rumusan tujuan pendidikan Islam tersebut, dinilai lebih bersifat global, kurang problematis, kurang strategis, kurang antisipatif terhadap persoalan-persoalan yang dihadapi umat manusia serta dianggap kurang menyentuh aspek aplikasi (psikomotorik). Tujuan tersebut, dinilai lebih 
bersifat teoritik normatif dan terkesan kurang strategis dalam memecahkan problem-problem yang dihadapi umat manusia, sementara problem yang dihadapi sangat kompleks, sedangkan tujuan praktis untuk meningkatkan daya saing lulusannya lebih sulit dipecahkan karena pada saat yang sama pendidikan Islam harus memenuhi tujuan yang disusun pada dataran metafisik yang sangat teoritik, normatif,sementara pada sisis lain, pendidikan Islam harus juga dituntut mampu menjawab tuntutan perubahan zaman yang begitu cepat.

\section{MEMBANGUN PARADIGMA PENDIDIKAN ISLAM MODERN}

Gerakan globalisasi dan liberasi perdagangan Internasional sedang berlangsung di pentas dunia, yang disertai dengan dampak yang luas bagi kehidupan manusia di segala aspek. Maka, bukan tidak mungkin pengaruh dari globalisasi dan perdagangan bebas ini, perlu mempersiapkan segala sesuatu dengan baik, agar mampu mengantisipasi segala kemungkinan yang terjadi. Sedangkan kalimat globalisasi menurut Ishomuddin, berasal dari kata "Globe" yang berarti "baca dunia", sehingga globalisasi disebut pula sebagai gerakan mendunia, yakni suatu perkembangan sistem dan nilai-nilai kehidupan yang bersifat global.

Apabila demikian yang terjadi, hal ini menjadi runtuhnya sekat yang membatasi pergaulan antar bangsa, apakah itu sekat ekonomi, politik, sosial dan budaya, karena akibat dari pengaruh gerakan globalisasi tersebut. Yang secara mendasar di bidang perekonomian negara-negara di dunia, berkembang secara ekspansif (meluas). Arus barang, jasa, modal, tehnologi dan informasi semakin meningkat, dikarenakan banyak negara di dunia semakin terbuka. Kekhawatiran yang terjadi adalah timbulnya jurang pemisah yang semakin melebar antara negara-negara maju dan negara-negara sedang berkembang bahkan bagi negara miskin (terlebih lagi negara yang masih konflik) sungguh naif nasibnya.

Begitulah masyarakat global diera globalisasi dewasa ini. Apalagi ditopang oleh kemajuan tehnologi, khususnya tehnologi komunikasi maka, seolah-olah manusia dengan yang lainnya menjadi dekat (menyatu) dalam satu keluarga. Tidak ada lagi sudut-sudut di bumi ini yang terisolasi berkat kemajuan tehnologi komunikasi. Sehingga manusia yang hidup dibelahan dunia manapun seakan tanpa sekat, akibat menipisnya batas-batas kenegaraan suatu bangsa dan akan terciptanya suatu sistem interaksi antar manusia dalam jagat raya secara lebih intensif, tentu dalam dimensi yang lebih luas. 
Akibat perluasan interaksi antar manusia bukan hanya dalam bentuk jaringan kerjasama saja, tetapi juga menimbulkan persaingan yang ekstra ketat. Artinya kekompleksitasan lingkungan akibat persaingan global akan menimbulkan tantangan yang lebih berat, maka saat ini bagaimana cara atau strategi untuk meningkatkan standar produk, jasa maupun kapabilitas seseorang dalam action untuk memenuhi kebutuhan hidup masyarakat pada umumnya. Sebagaimana digambarkan oleh Sukiswo Dirdjopuparto yang dikutip oleh Ishomuddin, ini merupakan progressive problem yang memerlukan kemampuan belajar dan kreatifitas lebih tinggi, ibarat pertandingan tingkat nasional berubah pada tingkat internasional, tentu persaingan akan lebih berat.

Dari uraian tersebut di atas bahwa globalisasi akan membawa sekian implikasi yang berupa pergeseran sistem dan nilai dalam setiap dimensi kehidupan umat manusia. Implikasi tersebut mempunyai aspek positif dengan suatu gambaran terciptanya masyarakat yang mega kompetitif artinya menumbuhkan semangat bagi setiap individu untuk selalu tampil secara kompetitif. Sedangkan implikasi negatif secara mendasar, bahwa tekanan kapitalisme internasional yang tidak ditopang oleh kesiapan SDM yang memadai akan menjadi obyek semata dan menimbulkan budaya konsumeristik serta materialistik. Maka Guna mengantisipasi untuk memperoleh manfaat dan juga bisa terlindung atau bahkan terhindar dari dampak negatif itu, masyarakat membutuhkan SDM yang tidak hanya bertaraf lokal, tetapi bertaraf Internasional, SDM yang tidak hanya berteori semata tetapi juga handal dalam prakteknya, SDM yang memiliki pengetahuan luas dan berkualitas tinggi sesuai dengan tuntutan zamannya.

Mengingat pendidikan merupakan kebutuhan penting bagi setiap manusia, baik itu negara maupun pemerintah, maka sepantasnya bila proses pendidikan hendaknya selalu memiliki orientasi ke depan bagi pemenuhan kebutuhan manusia di setiap zamannya, terutama bagi kepentingan generasi muda yang akan hidup dan dituntut untuk mampu menjawab persoalan pada masa yang akan datang.

Berangkat dari kerangka ini, maka upaya pendidikan yang dilakukan baik oleh suatu kelompok, golongan, bangsa, dan negara selalu harus memiliki hubungan yang signifikan bagi gambaran (prediksi) perkembangan zaman di masa mendatang, oleh karena itu bahwa proses pendidikan tidak bisa bersifat statis, dia (proses pendidikan), harus mampu meresponsperubahan, baik perubahan zaman maupun perubahan masyarakat. Dengan demikian, wajar 
kalau pendidikan harus selalu didesain mengikuti irama perubahan, kalau tidak pendidikan akan ketinggalan. Untuk itu, maka tuntutan pembaharuan pendidikan menjadi suatu keharusan di setiap jenis dan jenjang pendidikan (termasuk di dalamnya adalah pendidikan Islam). Pembaharuan pendidikan harus selalu mengikuti dan relevan dengan kebutuhan masyarakat, baik pada konsep, kurikulum, proses, fungsi, tujuan, manajemen lembaga, sumber daya pengelola pendidikan.

Secara mendasar bahwa format modernisasi ke sistem pendidikan pada dunia Islam, harus diakui oleh kaum muslim sendiri, bahwa hal tersebut berawal dari kalangan kaum non Islam. Sejak pertama kalinya sistem pendidikan dilakukan dengan model sangat sederhana di dunia Islam, yakni dengan menggunakan masjid, muslhollah (dalam bahasa Jawanya langgar) sebagai tempat belajar, bahkan ada juga menggunakan rumah kiainya untuk melakukan proses belajar, karena semakin banyak murid yang berdatangan terutama dari luar daerah dibuatlah sebuah asrama dengan melibatkan perpaduan di antara ketiga komponen tersebut adalah masjid, asrama dan rumah kiai dalam satu lingkungan, kesemuanya guna memperdalam ilmu-ilmu keislaman dan kurikulumnya pun belum bersifat klasikal, berjenjang secara teratur dengan kata lain formatnya masih sangat sederhana (dikenal tradisional).

Pembaharuan pendidikan terjadi karena adanya tantangan kebutuhan masyarakat pada saat itu dan lewat proses pendidikan itu sendiri diharapkan dapat menyiapkan produk manusia yang mampu mengatasi kebutuhan masyarakat yang tidak saja hanya persoalan agama (religius) tetapi persoalan kehidupan manusia pada umumnya, seperti sekarang ini. Sehingga dapat dikatakan bahwa pendidikan tidak hanya sebatas sebagai fungsi inkulturasi, yakni sekedar berfungsi sebagai pewaris nilai-nilai yang ada sekarang ke generasi mendatang, tetapi lebih dari itu hendaknya juga diarahkan untuk menyiapkan generasi dalam menghadapi tantangan hidup di masanya.

Apabila mengamati awal-awal gagasan modernisasi Islam di wilayah pendidikan, telah direalisasikannya lembaga-lembaga pendidikan modern yang di adopsi dari sistem pendidikan Barat. Mencermati konsep pendidikan ini, maka pembaharuan pendidikan Islam merupakan suatu usaha atau proses multidimensional yang cukup kompleks, dan tidak hanya bertujuan untuk menyempurnakan kekurangan-kekurangan yang dirasakan, tetapi lebih utama merupakan suatu usaha penelaahan kembali atas aspek-aspek sistem pendidikan yang berorientasi pada rumusan 
tujuan yang baru dan lebih utama selalu berorientasi pada perubahan masyarakat.

Guna menindaklanjuti tingkat perkembangan kebutuhan hidup masyarakat yang demikian kompleks disertai dengan saratnya perubahan dalam berbagai bidang kehidupan, dengan tingkat kompetitif yang sangat tinggi akibat proses modernisasi, globalisasi dan liberasi, maka setidaknya pendidikan Islam harus mampu memberikan jawaban dan siap melakukan paradigma pembaharuan pendidikan Islam di segala aspek, sehingga mampu melahirkan, mencetak, memproduk dan menghasilkan manusia yang berkualitas tinggi sebagaimana harapan masyarakat luas, hal itu dilakukan semata-mata untuk merespons kebutuhan masyarakat luas bila pendidikan Islam tidak ingin ditinggalkan oleh komunitasnya (umat).

Pendidikan Islam tidak bisa lagi bertahan dalam posisi dan perannya yang bersifat tradisional kepada generasi berikutnya. Karena bagaimanapun, pendidikan Islam dituntut melakukan fungsi yang bersifat reflektif dan juga progresif. Dalam fungsi yang pertama, pendidikan Islam harus mampu menggambarkan corak dan arus kebudayaan yang sedang berlangsung, sedangkan fungsi kedua pendidikan Islam dituntut mampu memperbaharui dan mengembangkan kebudayaan agar dicapai kemajuan. Pada fungsi yang kedua ini maka pendidikan Islam harus segera melakukan langkah transformatifnya.

Memang, lebih rinci lembaga pendidikan Islam telah teridentifikasi sebagaimana menurut Zarkowi Syuyuti yang dikutip oleh Abdul Halim Soebahar, menjelaskan bahwa: Pertama pendidikan Islam adalah jenis pendidikan yang penyelenggaraannya di dorong oleh hasrat dan semangat cita-cita untuk mengejawantahkan nilai-nilai Islam, baik yang tercermin dalam nama lembaganya maupun dalam kegiatan-kegiatan yang diselenggarakan. Kedua pendidikan Islam adalah jenis pendidikan yang memberikan perhatian dan sekaligus memberikan ajaran Islam sebagai pengetahuan untuk program studi, sebagai ilmu dan diperlakukan sebagaimana ilmu-ilmu yang lain. Ketiga pendidikan Islam adalah jenis pendidikan yang mencakup kedua dari pengertian tersebut.

Dari rincian tersebut, maka kata "Islam" ditempatkan sebagai sumber nilai sekaligus sebagai bidang studi yang ditawarkan lewat program studi yang diselenggarakan. Kiranya bisa di pahami bahwa eksistensi pendidikan Islam tidak sekedar menyangkut ketiga-tiganya, karena memang ketiga-tiganya itu yang selama ini sudah tumbuh dan berkembang sebagai bentuk realitas yang terjadi dan menjadi bagian yang tak terpisahkan dari andil umat Islam untuk turut serta 
memberdayakan umat. Bila dikaji lebih lanjut paradigma pembaharuan pendidikan Islam akhir-akhir ini lebih mengarah pada pembaharuan yang bersifat sistemik, bukan parsial, dan itu dikenal dengan reformasi. Agar reformasi tidak menjelma sebagai "bola liar", maka diperlukan platform, dengan tujuan agenda reformasi tersebut memiliki arah dan koridor yang jelas (bukan hanya sekedar pergantian kursi jabatan dan penambahan fasilitas serta perubahan materi semata), sehingga akan dihasilkan suatu konstruk hasil pembaharuan pendidikan Islam yang secara konseptual dapat diterima oleh logika, secara kultural sesuai dengan budaya bangsa dan secara politis dapat diterima di kalangan masyarakat luas. Dalam proses perubahan tersebut, minimal diharapkan pendidikan Islam mampu mengembangkan dua peran sebagai pandangan strategisnya, yakni pertama; pendidikan Islam bisa mempengaruhi terhadap perubahan masyarakat dan kedua; pendidikan Islam mampu memberikan sumbangan optimal terhadap proses transformasi menuju terwujudnya masyarakat yang berdaya.

Dengan demikian, maka pendidikan Islam secara kultural perlu mempertegas kembali orientasinya. Reorientasi yang perlu dilakukan adalah perlunya mempertegas kembali posisi dan peran pendidikan Islam tersebut. Baik dalam gerak transformasi sosial, kultural dan struktural yang demikian cepat dan bersifat universal seperti sekarang ini.

Ketika pendidikan Islam telah menjelma sebagai wacana maupun praksisnya di era modernisasi, globalisasi dan liberasi, maka wajar jika pendidikan Islam dituntut merumuskan kembali visi dan misinya. Visi pendidikan Islam merupakan suatu wawasan atau keyakinan bersama seluruh komponen lembaga akan keadaan masa depan yang diinginkan. Visi ini setidaknya akan memberikan inspirasi dan mendorong seluruh komponen lembaga untuk bekerja lebih giat dan efektif. Setidaknya, Visi ini harus dinyatakan dalam kalimat yang jelas, positif maupun realistis. kalau visi pendidikan Islam merupakan pernyataan tentang gambaran global masa depan pendidikan Islam, maka misi merupakan pernyataan formal tentang tujuan utama yang akan direalisir. Jadi visi merupakan ide, citacita, wawasan dan gambaran di masa depan yang tidak terlalu jauh, maka misi merupakan upaya kongkritisasi visi dari wujud tujuan dasar pendidikan Islam yang akan diwujudkan. Visi dan misi pendidikan Islam itu pada akhirnya akan terus membayangi segenap SDM atau segenap warga suatu lembaga, pimpinan, pendidik, peserta didik, wali peserta didik, sesuai dengan kapasitas dan fungsi masing-masing untuk bekerja secara efektif berdasar misi guna mewujudkan visi yang sudah di idealitaskan. 


\section{PENUTUP}

Perubahan yang terjadi dalam kehidupan masyarakat baik sosial maupun kultural, secara makro persoalan yang dihadapi pendidikan Islam adalah bagaimana pendidikan Islam mampu menghadirkan disain atau konstruksi wacana pendidikan Islam yang relevan dengan perubahan masyarakat. Kemudian disain wacana pendidikan Islam tersebut dapat dan mampu ditransformasikan atau diproses secara sistematis dalam masyarakat. Persoalan pertama ini lebih bersifat filosofis, yang kedua lebih bersifat metodologis. Pendidikan Islam perlu menghadirkan suatu konstruksi wacana pada dataran filosofis, wacana metodologis, dan juga cara menyampaikan atau mengomunikasikannya. Dalam menghadapi peradaban modern, yang perlu diselesaikan adalah persoalan-persoalan umum internal pendidikan Islam yaitu (1) persoalan dikotomik, (2) tujuan dan fungsi lembaga pendidikan Islam, (3) persoalan kurikulum atau materi. Ketiga persoalan ini saling interdependensi antara satu dengan lainnya.

Pertama, Persolan dikotomik pendidikan Islam, yang merupakan persoalan lama yang belum terselesaikan sampai sekarang. Pendidikan Islam harus menuju pada integritas antara ilmu agama dan ilmu umum untuk tidak melahirkan jurang pemisah antara ilmu agama dan ilmu bukan agama. Karena, dalam pandangan seorang Muslim, ilmu pengetahuan adalah satu yaitu yang berasal dari Allah SWT. Kedua, perlu pemikiran kembali tujuan dan fungsi lembaga-lembaga pendidikan Islam (Anwar Jasin, 1985 : 15) yang ada. Memang diakui bahwa penyesuaian lembaga-lembaga pendidikan akhir-akhir ini cukup memberikan, artinya lembaga-lembaga pendidikan memenuhi keinginan untuk menjadikan lembaga-lembaga tersebut sebagai tempat untuk mempelajari ilmu umum dan ilmu agama serta keterampilan. Ketiga, persoalan kurikulum atau materi Pendidikan Islam, meteri pendidikan Islam "terlalu dominasi masalah-masalah yang bersifat normatif, ritual dan eskatologis. Materi disampaikan dengan semangat ortodoksi kegamaan, suatu cara di mana peserta didik dipaksa tunduk pada suatu "meta narasi" yang ada, tanpa diberi peluang untuk melakukan telaah secara kritis. Pendidikan Islam tidak fungsional dalam kehidupan sehari-hari, kecuali hanya sedikit aktivitas verbal dan formal untuk menghabiskan materi atau kurikulum yang telah diprogramkan dengan batas waktu yang telah ditentukan. 


\section{DAFTAR PUSTAKA}

Abbas, S., Tabrani ZA, \& Murziqin, R. (2016). Responses of the Criminal Justice System. In International Statistics on Crime and Justice (pp. 87-109). Helsinki: HEUNI Publication.

Abdullah, A., \& Tabrani ZA. (2018). Orientation of Education in Shaping the Intellectual Intelligence of Children. Advanced Science Letters, 24(11), 8200-8204. https://doi.org/10.1166/as1.2018.12523

Abtahi, M., \& Battell, C. (2017). Integrate Social Justice Into the Mathematics Curriculum in Learning. Jurnal Ilmiah Peuradeun, 5(1), 101-114. doi:10.26811/peuradeun.v5i1.123

Abudin Nata. (2009). Rekonstruksi Pendidikan Islam. Jakarta: Rajawali Press.

Achmadi, 2008, Ideologi Pendidikan Islam: Paradigma Humanis Teosentris. Yogyakarta: Pustaka Pelajar.

Acosta, M. (2016). Paradigm Shift in Open Education and E-Learning Resources as Teaching and Learning in Philippines. Jurnal Ilmiah Peuradeun, 4(2), 161-172. doi:10.26811/peuradeun.v4i2.94

AR, M., Usman, N., Tabrani ZA, \& Syahril. (2018). Inclusive Education Management in State Primary Schools in Banda Aceh. Advanced Science Letters, 24(11), 8313-8317. https://doi.org/10.1166/as1.2018.12549

Buseri, K. (2015). Epistemologi Islam dan Reformasi Wawasan Pendidikan. Jurnal Ilmiah Peuradeun, 3(1), 77-102.

Chalim, A. (2018). Effect of Job-Insecurity, Organizational Commitment, Job Satisfaction on Turnover Intention: A Case Study of Newcomer Lecturers at Private Islamic Universities in East Java Province, Indonesia. Jurnal Ilmiah Peuradeun, 6(2), 199-214. doi:10.26811/peuradeun.v6i2.284

Fatimatuzzahroh, F., Abdoellah, O. S., \& Sunardi, S. (2015). The Potential of Pesantren In Sustainable Rural Development. Jurnal Ilmiah Peuradeun, 3(2), 257-278.

Hadi, A. (2017). The Internalization of Local Wisdom Value in Dayah Educational Institution. Jurnal Ilmiah Peuradeun, 5(2), 189-200. doi: $10.26811 /$ peuradeun.v5i2.128

Haynes, J. (2015). Religion in Global Politics: Explaining Deprivatization. Jurnal Imiah Peuradeun, 3(2), 199-216.

Hughes, K., \& Batten, L. (2016). The Development of Social and Moral Responsibility in Terms of Respect for the Rights of Others. Jurnal Ilmiah Peuradeun, 4(2), 147-160. doi:10.26811/peuradeun.v4i2.93

Huwaida, H. (2015). Change and Development in the Acehnese Dayah Salafi (A Case Study). Jurnal Imiah Peuradeun, 3(2), 279-294.

Idris, S., \& Tabrani ZA. (2017). Realitas Konsep Pendidikan Humanisme 
dalam Konteks Pendidikan Islam. Jurnal Edukasi: Jurnal Bimbingan Konseling, 3(1), 96-113. https://doi.org/10.22373/je.v3i1.1420

Idris, S., Tabrani ZA, \& Sulaiman, F. (2018). Critical Education Paradigm in the Perspective of Islamic Education. Advanced Science Letters, 24(11), 8226-8230. https://doi.org/10.1166/as1.2018.12529

Imam Bawani. (2015). Metodologi Penelitian Pendidikan Islam. Sidoarjo: Khazanah Ilmu Sidoarjo.

Imam Nawawi. (1999). Muqaddimah al-Majmu: Cairo: Maktabah al-Balad al-Amin.

Ismail Thoib. (2008). Wacana Baru Pendidikan: Meretas Filsafat Pendidikan Islam. Yogyakarta: Genta Press.

Karibi, R. A. I. N. (2015). Religion, Human Rights and the Challenges of Freedom. Jurnal Ilmiah Peuradeun, 3(1), 39-54.

Kaylene, P., \& Rosone, T. (2016). Multicultural Perspective on the Motivation of Students in Teaching Physical Education. Jurnal Ilmiah Peuradeun, 4(1), 115-126. doi:10.26811/peuradeun.v4i1.90

La Torre, C., \& Montalto, K. (2016). Transmigration, Multiculturalism and Its Relationship to Cultural Diversity in Europe. Jurnal Ilmiah Peuradeun, 4(1), 39-52. doi:10.26811/peuradeun.v4i1.84

Lewis, M., \& Ponzio, V. (2016). Character Education as the Primary Purpose of Schooling for the Future. Jurnal Ilmiah Peuradeun, 4(2), 137-146. doi:10.26811/peuradeun.v4i2.92

Lvina, E. (2015). The Role of Cross-Cultural Communication Competence: Effective Transformational Leadership Across Cultures. Jurnal Ilmiah Peuradeun, 3(1), 1-18.

Marzuki, M. (2016). Diniyyah in Public Schools: A Model of Islamic Curriculum Implementation in Multi Religious Society in Banda Aceh-Indonesia. Jurnal Ilmiah Peuradeun, 4(1), 15-26. doi: $10.26811 /$ peuradeun.v4i1.82

Meraj, M. (2016). Islamic Approach to the Environment and the Role's in the Environment Protected. Jurnal Ilmiah Peuradeun, 4(1), 1-14. doi:10.26811/peuradeun.v4i1.81

Murziqin, R., \& Tabrani ZA (2017). A Consequence of Institutionalized Political Inequality. Journal of Political Sciences \& Public Affairs, 4(3), 231-242

Murziqin, R., \& Tabrani ZA. (2016). The Importance of Local Parties and Incumbency to the Electoral in Aceh. Journal of Islamic Law and Culture, 10(2), 123-144.

Murziqin, R., Tabrani ZA, \& Zulfadli. (2012). Performative Strength in the Hierarchy of Power and Justice. Journal of Islamic Law and Culture, 10(2), 123-144.

Musradinur, \& Tabrani ZA. (2015). Paradigma Pendidikan Islam Pluralis 
Sebagai Solusi Integrasi Bangsa (Suatu Analisis Wacana Pendidikan Pluralisme Indonesia). 1st Annual International Seminar on Education 2015, 77-86. Banda Aceh: FTK Ar-Raniry Press.

Ninoersy, T., Tabrani, Z. A., \& Wathan, N. (2019). Manajemen Perencanaan Pembelajaran Bahasa Arab Berbasis Kurikulum 2013 pada SMAN 1 Aceh Barat. FITRAH: Jurnal Kajian Ilmu-ilmu Keislaman, 5(1), 83-102.

Obasa, D., \& Adebule, J. (2017). The Challenges of Higher Education in Growing Dialogue Culture and Understanding Cultural Pluralism. Jurnal Imiah Peuradeun, 5(3), $401 \quad$ - 414. doi:10.26811/peuradeun.v5i3.183

Patimah, S., \& Tabrani ZA. (2018). Counting Methodology on Educational Return Investment. Advanced Science Letters, 24(10), 7087-7089. https://doi.org/10.1166/as1.2018.12414

Remaja Rosdakarya.

Rouhana, H. (2015). Feminism National Identity. Jurnal Ilmiah Peuradeun, 3(3), 353-362.

Siswanto, R., Sugiono, S., \& Prasojo, L. (2018). The Development of Management Model Program of Vocational School Teacher Partnership with Business World and Industry Word (DUDI). Jurnal Ilmiah Peuradeun, 6(3), 365-384. doi:10.26811/peuradeun.v6i3.322

Sudarsana, I. (2016). Development Model of Pasraman Kilat Learning to Improve the Spiritual Values of Hindu Youth. Jurnal Ilmiah Peuradeun, 4(2), 217-230. doi:10.26811/peuradeun.v4i2.99

Suzanne, R., \& Nathalie, L. (2016). Multiculturalism as an Alternative A Cultural Orientation to Education in the Aspect of Culture as the Axiological Focus. Jurnal Ilmiah Peuradeun, 4(3), 383-394. doi:10.26811/peuradeun.v4i3.111

Tabrani ZA \& Murziqin, R. (2015). Political Education in Maturation Democracy in Indonesia. British Journal of Political Science, 45 (1), 215-226

Tabrani ZA, \& Hayati. (2013). Buku Daras Ulumul Quran (1). Yogyakarta: Darussalam Publishing.

Tabrani ZA, \& Masbur. (2016). Islamic Perspectives on the Existence of Soul and Its Influence in Human Learning (A Philosophical Analysis of the Classical and Modern Learning Theories). JURNAL EDUKASI: Jurnal Bimbingan Konseling, 1(2), 99-112. Retrieved from http://jurnal.arraniry.ac.id/index.php/cobaBK/article/view/600

Tabrani ZA, \& Walidin, W. (2017). Hak-Hak Non Muslim dalam Pemerintahan: Konsep Dien wa Ni'mah dan Pluralisme Agama di Indonesia. Ijtima $i$ : International Journal of Government and Social Science, 3(1), 15-30.

Tabrani ZA. (2008). Mahabbah dan Syariat. Kuala Lumpur: Al-Jenderami Press. 
Tabrani ZA. (2009). Ilmu Pendidikan Islam (antara Tradisional dan Modern). Kuala Lumpur: Al-Jenderami Press.

Tabrani ZA. (2011a). Dynamics of Political System of Education Indonesia. International Journal of Democracy, 17(2), 99-113.

Tabrani ZA. (2011b). Nalar Agama dan Negara dalam Perspektif Pendidikan Islam. (Suatu Telaah Sosio-Politik Pendidikan Indonesia). Millah Jurnal Studi Agama, 10(2), 395-410.

Tabrani ZA. (2011c). Pendidikan Sepanjang Abad (Membangun Sistem Pendidikan Islam di Indonesia Yang Bermartabat). 41-66. Yogyakarta: MSI UII.

Tabrani ZA. (2012a). Future Life of Islamic Education in Indonesia. International Journal of Democracy, 18(2), 271-284.

Tabrani ZA. (2012b). Hak Azazi Manusia dan Syariat Islam di Aceh. International Conference Islam and Human Right, 123-142. Yogyakarta: MSI UII.

Tabrani ZA. (2013a). Modernisasi Pengembangan Pendidikan Islam (Suatu Telaah Epistemologi Pendidikan). Serambi Tarbawi, 1(1), 65-84.

Tabrani ZA. (2013b). Pengantar Metodologi Studi Islam. Banda Aceh: SCAD Independent.

Tabrani ZA. (2013c). Urgensi Pendidikan Islam dalam Pemberdayaan Masyarakat. Jurnal Sintesa, 13(1), 91-106.

Tabrani ZA. (2013d). Kebijakan Pemerintah dalam Pengelolaan Satuan Pendidikan Keagamaan Islam (Tantangan Terhadap Implementasi Manajemen Berbasis Sekolah). Serambi Tarbawi, 1(2), 65-84.

Tabrani ZA. (2014a). Buku Ajar Filsafat Umum. Yogyakarta: Darussalam Publishing.

Tabrani ZA. (2014b). Dasar-Dasar Metodologi Penelitian Kualitatif. Yogyakarta: Darussalam Publishing.

Tabrani ZA. (2014c). Islamic Studies dalam Pendekatan Multidisipliner (Suatu Kajian Gradual Menuju Paradigma Global). Jurnal Ilmiah Peuradeun, 2(2), 211-234.

Tabrani ZA. (2014d). Isu-Isu Kritis dalam Pendidikan Islam Perspektif Pedagogik Kritis. Jurnal Imiah Islam Futura, 13(2), 250-270. https://doi.org/10.22373/jiif.v13i2.75

Tabrani ZA. (2014e). Menelusuri Metode Pendidikan dalam Al-Qur'an dengan Pendekatan Tafsir Maudhu i. Serambi Tarbawi, 2(1), 19-34.

Tabrani ZA. (2014f). Penelitian Tindakan Kelas (Buku Ajar)-Bahan Ajar untuk Mahasiswa Program Strata Satu (S-1) dan Program Profesi Keguruan (PPG). Banda Aceh: FTK Ar-Raniry Press.

Tabrani ZA. (2015a). Arah Baru Metodologi Studi Islam. Yogyakarta: Penerbit Ombak. 
Tabrani ZA. (2015b). Persuit Epistemology of Islamic Studies (Buku 2 Arah Baru Metodologi Studi Islam). Yogyakarta: Penerbit Ombak.

Tabrani ZA. (2015c). Keterkaitan Antara Ilmu Pengetahuan dan Filsafat (Studi Analisis atas QS. Al-An`am Ayat 125). Jurnal Sintesa, 14(2), 114.

Tabrani ZA. (2016a). Perubahan Ideologi Keislaman Turki (Analisis GeoKultur Islam dan Politik Pada Kerajaan Turki Usmani). JURNAL EDUKASI: Jurnal Bimbingan Konseling, 2(2), 130-146. https://doi.org/10.22373/je.v2i2.812

Tabrani ZA. (2016b). Transformasi Teologis Politik Demokrasi Indonesia (Telaah singkat Tentang Masyarakat Madani dalam Wacana Pluralisme Agama di Indonesia). Al-Ijtima i-International Journal of Government and Social Science, 2(1), 41-56.

Tabrani ZA. (2017a). Menggugat Logika Nalar Rasionalisme Aristoteles. Yogyakarta: Mizan.

Tabrani ZA. (2017b). Restrukturrisasi untuk Pendidikan Bermutu. Research in Education, 12(1), 131-136.

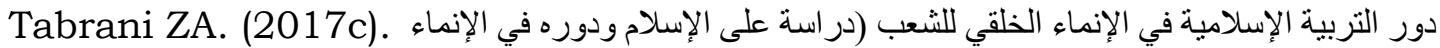
(القومي بإندونيسيا (J). Ar-Raniry, International Journal of Islamic Studies, 4(1), 101-116. https://doi.org/10.20859/jar.v4i1.128

Tabrani ZA. (2019). Social Change and Human Nature. In The New System's Need for Primitive Capital Accumulation (pp. 271-277). United Kingdom: Taylor \& Francis.

Tabrani ZA. (2019a). Constructive Ideas for Teaching Addition Skills. Research in Education, 14(2), 131-142.

Tabrani ZA. (2019b). Konfigurasi Pendidikan Karakter dalam Konteks Totalitas Proses Psikologis dan Sosial-Kultural. Ethics and Education, 12(1), 13-20.

Tabrani ZA., Idris, S., \& Hayati. (2019). Islam dan Kuasa Seksualitas Perempuan di Indonesia. Yin Yang: Jurnal Studi Islam, Gender dan Anak, 14(1), 17-32

Tan, C. (2015). Educative Tradition and Islamic School in Indonesia. Jurnal Ilmiah Peuradeun, 3(3), 417-430.

Usman, N., AR, M., \& Marzuki, M. (2016). The Influence of Leadership in Improving Personnel Performance at Traditional Islamic Boarding School (Dayah). Jurnal Ilmiah Peuradeun, 4(2), 205-216. doi:10.26811/peuradeun.v4i2.98

Usman, N., AR, M., Murziqin, R., \& Tabrani ZA. (2018). The Principal's Managerial Competence in Improving School Performance in Pidie Jaya Regency. Advanced Science Letters, 24(11), 8297-8300. https:// doi.org/10.1166/as1.2018.12545

Usman, N., AR, M., Syahril, Irani, U., \& Tabrani ZA. (2019). The implementation of learning management at the institution of modern 
dayah in aceh besar district. Journal of Physics: Conference Series, $1175(1)$, 012157. https://doi.org/10.1088/1742$6596 / 1175 / 1 / 012157$

Verlo, M. (2015). Religion, Church, Intimate Citizenship and Gender Equality. Jurnal Imiah Peuradeun, 3(1), 55-76.

Walidin, W., Idris, S., \& Tabrani ZA. (2015). Metodologi Penelitian Kualitatif $\&$ Grounded Theory. Banda Aceh: FTK Ar-Raniry Press.

Warisno, A., \& Tabrani ZA. (2018). The Local Wisdom and Purpose of Tahlilan Tradition. Advanced Science Letters, 24(10), 7082-7086. https://doi.org/10.1166/as1.2018.12413

Yusoff, M. Z. M., \& Hamzah, A. (2015). Direction of Moral Education Teacher To Enrich Character Education. Jurnal Ilmiah Peuradeun, 3(1), 119-132. 